\title{
Regionalization of health surveillance: a performance evaluation proposal in a health region in Brazil
}

\author{
Ana Coelho de Albuquerque 1 \\ Eduarda Ângela Pessoa Cesse 2 \\ Eronildo Felisberto 3 \\ Isabella Samico 4 \\ Liza Yurie Teruya Uchimura 5 \\ Nathalie Estima 6
}

\footnotetext{
1 Centro de Pesquisas Aggeu Magalhães. Fundação Oswaldo Cruz. Av. Prof. Moraes Rego, s/n. Cidade Universitária. Recife, PE, Brasil. CEP: $50.740-465$. E-mail: anacoelhoalbuquerque@gmail.com

2 Departamento de Saúde Coletiva. Fundação Oswaldo Cruz. Recife, PE, Brasil.

3,4 Instituto de Medicina Integral Prof. Fernando Figueira. Recife, Pernambuco, Brasil.

5 Departamento de Medicina Preventiva. Faculdade de Medicina. Universidade de São Paulo. São Paulo, SP, Brasil.

6 Secretaria Executiva de Vigilância em Saúde. Secretaria de Saúde do Estado de Pernambuco. Recife, PE, Brasil.
}

\begin{abstract}
Objectives: To evaluate the performance of the regionalization of the Vigilância em Saude (VS) (Health Surveillance) in a region in Sao Paulo State.

Methods: a quantitative cross-sectional study was carried out at the V Diretoria Regional de Saúde da Secretaria de Saúde do Estado de São Paulo (V Board of the Regional Health Secretary of São Paulo State Health Department). A structured questionnaire was developed from the three dimensions of the research (Policy, Structure and Organization). The escore médio (EM) (average score) was used as the central tendency and for each dimension and attributes, the synthetic indices were constructed. Three cutoff points for assessing the performance were assigned: values equal to or below 4.99 were considered unsatisfactory; between 5.00 and 6.99, intermediaries; and equal to or above 7.00, satisfactory.

Results: The performance of the regionalization of the VS was considered satisfactory, with emphasis on the 'Policy' (EM 8.51) and 'Organization' (EM 8.18) dimensions. The 'Structure' obtained intermediate performance (EM 6.78). The proposed methodology demonstrated to be appropriate to evaluate the performance of the regionalization of VS, because its strengths and weaknesses were allowed to be identified.

Conclusions: despite of the regionalization is an ongoing process, it is necessary for the establishment of a political project that will take up effectively as a strategy for the reorganization of the healthcare in Brazil.
\end{abstract}

Key words Public health surveillance, Regionalization health planning, Health evaluation, Performance evaluation 


\section{Introduction}

In Brazil, during the 1990s, the prioritized strategy by the National policy to construct a universal health system, equitable and integral was the decentralization, having as its main focus the city. However, the balance that made this decentralization model adopted by the Sistema Único de Saúde (SUS) (Public Health System) is that, initially, it was important for the expansion of coverage in services and public resources from the State and City spheres, but they were not able to provide the integration of services, institutional and practices in the territories, nor the arrangements of the most cooperative formation in health. ${ }^{1}$ Thus, the conditions for a decentralization project that adhered to the purposes of the National health policy were not achieved. As a result, it is perceived that their results are contradictory and highly dependent on the previous local conditions. ${ }^{2}$

In the attempt to overcome the limitations resulting from the city, regionalization came to be prioritized as an organizational macro-strategy of the Brazilian health system. However, a study performed by Vargas et al., 3 who analyzed the regionalization in Brazil, concluded that this process has low deployment and development, though it depends on complex responsibilities of the regional entity and the fragile co-responsibility of the State and Federal levels. In addition, it is known that the characteristics of the decentralized health systems are quite heterogeneous in National territory, and they reflect on different financial, administrative and operational capacities for the healthcare provision and the distinct policy provisions of the governments. 4

In regards to the Health Surveillance (VS), it is well known that since the beginning of the construction process and deployment of SUS was debated a coherent proposal with the necessity to reorganize and reorient the health services in the Country. ${ }^{5}$ For this purpose, the VS has a fundamental role from a technical-operational point of view, to allow the reorientation of the work process to recognize the territory as a fundamental concept and, in this space, seeking to establish the definition of problems and priorities, as well as the set of means to effectively attend the health necessities in the community, through activities that involve the production of information and the development of actions in promoting, preventing and controlling the diseases, ${ }^{6}$ without losing sight of the regionalization of the National health system guideline.

In this context of organizational changes, the need to emerge the strategies design that contribute with the improvement of the performance and responds to the institutional necessities of the Sistema Nacional de Vigilância em Saúde (SNVS) ${ }^{7}$ (National Health Surveillance System), aligned with current perspectives of regionalization of SUS. It is necessary to highlight the studies that approach the theme on VS as a regional perspective, with the intention of strengthening this strategy. Thus, several authors 8,9 indicate the performance of evaluation as a strategy inducing changes capable of promoting greater accountability, transparency and continuous improvement of quality in the health services. And, although there is no consensus on how to measure the performance of the health systems and services, this can be defined to fulfill the objectives of the organizations that make up the system. 10

In Brazil, the performance in the health sector is still little explored, especially as it applies to VS.7 There are, as examples, a study conducted by Silva Júnior, 11 which evaluated the performance of SNVS by means of a composed indicator and recently, a study conducted by Teixeira et al.,12 who evaluated the SNVS in the Regulamento Sanitário Internacional (International Health Regulations). However, these studies presented concepts and different approaches bringing to the discussion in the performance in SUS subsystem. Therefore, it is understood that to reflect on the performance, identifying an evaluation template with a higher potential explanatory and suitable to the reality of the regionalization of VS, it is still a challenge. In this sense, the objective of this study is to evaluate the performance of the regionalization of VS in a region in São Paulo State, from a methodology developed for this purpose, with the aim of contributing to the discussion of this theme.

\section{Methods}

This is a cross-sectional quantitative case study which is an integral part of the research on Politica, Planejamento e Gestão das Regiões e Redes de Atenção à Saúde no Brasil (Policy, Planning and Management of Regions and Healthcare Networks in Brazil). The location of the study was at the Diretoria Regional de Saúde $V$ (DRS-V) da Secretaria de Saúde do Estado de São Paulo (SESSP) (Board of Regional Health Secretary V of the Health Department in São Paulo State), subdivided into the North and South Barretos regions composed by the following Cities: Altair, Barretos (headquarters), Bebedouro, Cajobi, Colina, Colômbia, Guaíra, Guaraci, Jaborandi, Monte Azul, Paulista, Olímpia, Severínia, Taiaçu, Taiúva, Taquaral, Terra Roxa, 
Viradouro and Vista Alegre do Alto.

The health region was selected intentionally by taking as a basis of the 436 health regions constituted in the Brazilian territory, from the typology study proposed by Viana et al. 13 The research sample was non-probabilistic type, in which the Cities in the region were selected by convenience. The Cities were selected with the highest capacity installed in health for the North-Barretos (Olímpia) and South Barretos (Bebedouro) regions, and the lowest capacity installed and with a significant population from both regions (Cajobi and Taiúva), in addition to the Cities headquarters of the DRS-V (Barretos), making a total of five studied Cities. The key agents participated in this research for the VS in the respective regions, the City and regional sphere. These informants were identified according to the occupation of the main VS organs.

For the evaluation of the performance on the VS regionalization, a structured questionnaire was developed for primary quantitative data collection, applied to the key agents of the health regions. This questionnaire was elaborated by a network of researchers from 18 institutions, distributed by 5 Brazilian regions, based on the policy, structural and organizational aspects of the regionalization process of VS, taking as a basis of the three research dimensions (Policy, Structure and Organization) (Figure 1). Subsequently, this questionnaire was validated by a group of experts, formed by 15 professionals in the area of the VS and five of the health evaluation, taking as a basis the technique called 'Consensus Conference', 14 adapted for the purposes of this research.

In the first stage, the experts of the VS received by e-mail a file containing the questions for the questionnaire. Each one of them discussed the questions, proposing changes in the text, deleting or adding questions and answers from each expert individually stored in a database for later analysis and consolidation by the research team. In the second step, a meeting was held in person with the total number of experts, enabling discussion on the proposed alterations, as well as the reflection of their experience and knowledge accumulated by each one. At the end of this discussion, questions were added or deleted, as well as the alterations on the text were consolidated. In the third and final step, some consolidated information discussed in the second stage was submitted only to the group of experts in health evaluation, which they only adjusted the writing.

The survey instrument was composed of questions expressed in the Likert scale 15 of five points in which the value of one (1) is equivalent to the worst evaluation and the five (5) to the best evaluation. The answers to these questions were arranged in frequency range (always, almost always, sometimes, rarely, never or don't know), of importance (very high, high, average, low, very low or don't know) or dichotomous (yes or no). The questionnaire also contained multiple-choice questions and open questions.

The group of respondents was composed by managers of the VS, but when the organization chart of the City did not include a specific manager of VS, then, Epidemiological Surveillance, Environmental and Health managers were interviewed. The questionnaires were applied with six City managers and two managers from the regional instance making a total of eight interviewed managers.

In order to seize the empirical reality and the operationalization of the evaluation in the Structure and Organization dimensions, the concept of a design tracer was used.16 The conditions that the design tracer adopted in this study were dengue fever and tuberculosis, selected by presenting the following characteristics: a) high prevalence and dissemination throughout the National territory; $b$ ) by the fact that there are explicit normative criteria for the diagnosis and treatment for these diseases; $c$ ) by having programs to prevent and established control with actions and determined flows among various managers.

\section{Indice of regionalization performance}

For the analysis of the regionalization performance, according to the dimensions and attributes the following variables were elected (Table 1):

The average score (EM) was the measurement of the central tendency selected for the analysis of the results of the questions arranged on the Likert scale which varies on a scale from 1 to 10 . In addition, for each attribute were constructed synthetic indices, also expressed in a scale of 1 to 10 , composed by average results of the variables. The performance indice is the aggregate of each dimension in the study (Policy, Structure and Organization), according to the attributes and indicators, as well as the general aggregate in the region, considering the three dimensions in the study.

Three cutoff points were attributed for evaluating the performance of each dimension, attribute and final performance in the region: values equal to or below 4.99 were considered unsatisfactory; between 5.00 and 6.99, intermediaries; and equal to or above 7.00 , satisfactory. For the dichotomous and 


\section{Figure 1}

Analytical Scheme: Policy, Structure and Organization Dimensions.

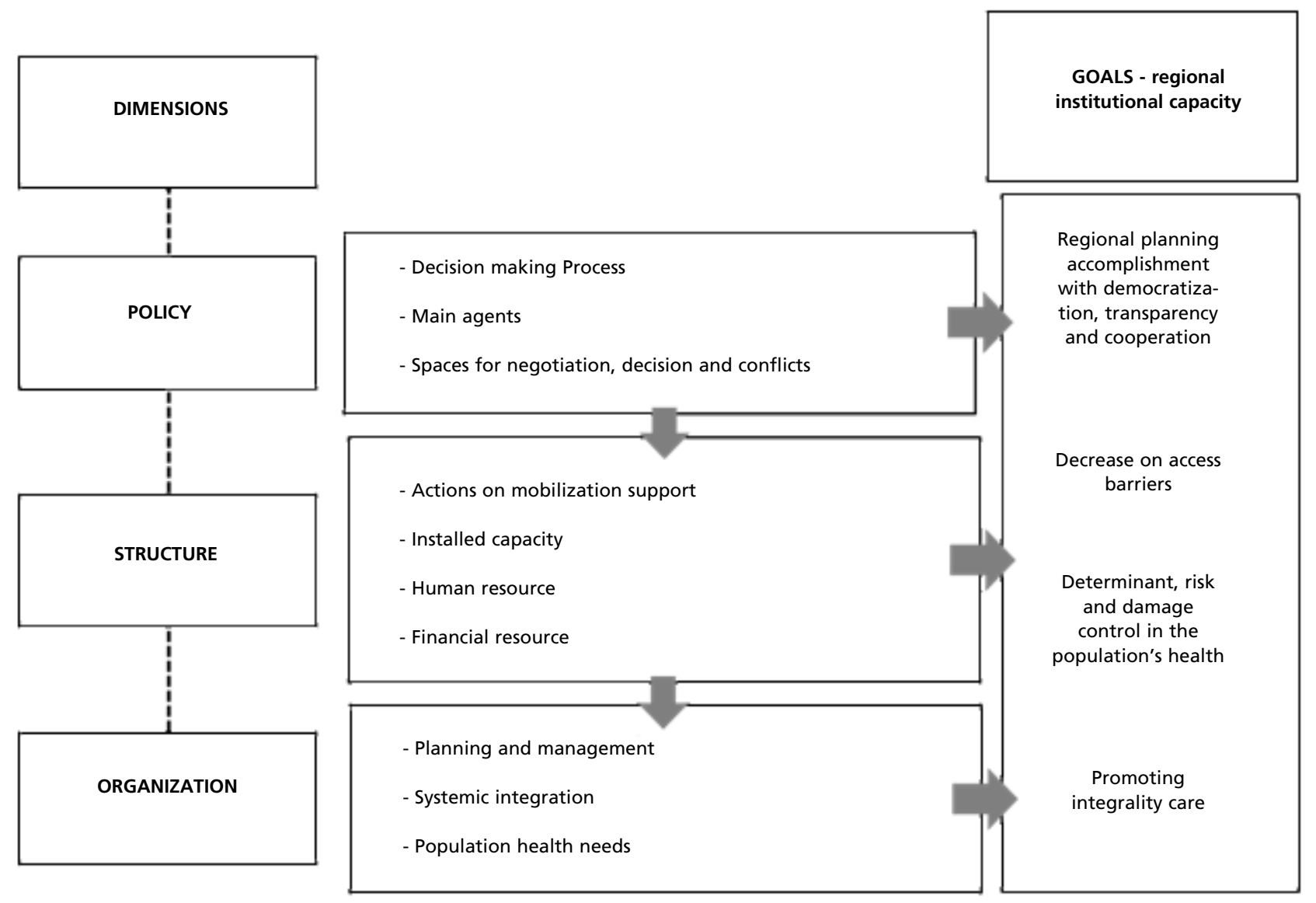


Dimensions, Attributes and Variables to evaluate the regionalization performance.

\begin{tabular}{ll}
\hline Dimension $\quad$ Attribute & Description of the variables \\
\hline
\end{tabular}

Policy Protagonism of the health region

Importance of the CIR

Structure

Actions on mobilization support

Financial Sufficiency

Human resource sufficiency

Physical resources sufficiency

Organization Planning and management

Integrating

Determinants, risks and damage control to health
Important reference to: public organs of the health system organization, civil society organizations, academic institutions and participative councils.

Important reference of the Comissão Intergestores Regional (CIR) (Regional Intermanagers Commission) in discussion of topics related to VS.

Actions on mobilization support of VS.

Participation of local, state, and city spheres of VS costing; execution percentage on resources of the Piso Fixo e Variável da Vigilância e Promoção da Saúde (PFVVPS) (Fixed and Surveillance variable and Health promotion); investment for the VS in the region.

Human resource sufficiency by categories of professionals.

Structure sufficiency; input mobilization, medications and tests to control tuberculosis and dengue fever programs.

For the parameters used in VS planning; definition of practices and work processes and management contribution.

Integration of Inter and intra-sectoral; mechanisms of VS integration with Atenção Primária à Saúde (APS) (Primary Health Care).

Frequency of diseases of closed compulsory notification by laboratory criteria; frequency of sending laboratory exams samples to VS for analysis in another health region; carrying out on tuberculosis control actions; consolidation and analysis on data generated by the Sistemas de Informação (SIM, Sinan etc.) (Information Systems); monitoring resistant tuberculosis cases and multidrug resistant; carrying out on actions to control dengue fever. 
multinomial questions, the use of the percentage in affirmative and/or positive responses in relation to the investigated item was chosen. All questions were tabulated in Excel software and the statistical analysis was performed by using SPSS for Windows, version 21.0 (Armonk, NY).

Regarding to the open questions, an analysis was made as a topic type with the goal to identify nucleus of meaning that made up the communication of the interviewees whose presence or repetition in the various speeches had meaning for the object of analysis investigated.17 The data considered relevant were inserted in an orderly and chronological order in a matrix analysis with the intention to facilitating understanding, interpretation and analysis of the material.

The research was approved by the Human Research Ethics Committee at the Faculdade de Medicina da Universidade de São Paulo (FMUSP) with the protocol number 071/2015.

\section{Results}

The regionalization performance of the VS in DRSV in São Paulo State according to the methodology proposed was considered satisfactory (EM 7.82), with emphasis on the Policy dimension, which obtained the EM satisfactory (8.16), followed by the Organization dimension (EM 8.02), whose performance has also been satisfactory, and the Structure (EM 6.78) with intermediate performance (Table 2).

\section{Policy Dimension}

The health region has reached a satisfactory position in relation to the Policy dimension, recognizing the importance of the CIR as a space to discuss issues of VS. Regarding to the protagonism of the region, it was noted that the importance given to the SES organs at central level and regional instance in the decision-making on VS (Table 3).

According to the interviewees, the main institution organizing the VS in the region is the Estrutura Regional da SES (Regional Structure of SES) (77.5\%), identified as the Departamento Regional de Saúde (DRS) (Regional Health Department), and then the SES central level (32.5\%). The other institutions listed in the questionnaire (Secretarias Municipais de Saúde (City Health Department) established providers of health services and universities) were not mentioned by the interviewees.

In regard to the importance of the organs, institutions/organizations and spaces for decision-making on the VS in the studied region were evaluated as relevant: the Comissão Intergestores Regional (CIR) (Regional Inter-managers Commission) (EM 8.31) the Conselho de Secretários Municipais de Saúde (COSEMS) (Council of City Health Secretaries (EM 8.06), the regional structure of SES and SES central level, both with EM 7.48. The civil society organizations, as well as the academic institutions did not reach the EM 7.0.

As the frequency of the discussions at the CIR meetings, $75.0 \%$ of the interviewees pointed out that the VS issues are always discussed. However, when asked about the main questions discussed, the respondents pointed out about the financing of actions, especially in respect to the control of arboviruses, as the main issue addressed.

\section{Structure Dimension}

The performance of the Structure dimension was affected mainly due to the classification of 'sufficiency' and 'insufficiency' attributes to human resources'. Since the investments for VS, the percentage of the deployment of the PFVVPS resources and the relative participation of Federal, State and City levels in costing of VS in the region presented intermediate evaluation. The insufficient professionals in almost all the categories studied were noted (Table 3 ).

For $62.5 \%$ of the respondents, the installed capacity of VS in the studied health region is adequate to the needs of the population. The frequency in mobilizing needed support to execute the VS actions obtained the best evaluation on the items "management on VS information systems", 'surveillance, prevention and control of transmittable diseases' and ' inherent risk control in products and health services' (EM 8.87; 8.65; 8.42, respectively).

The participation of the Federal sphere in VS costing in the region had obtained satisfactory results (EM 7.07), while the City and State spheres had intermediate and unsatisfactory results (EM 6.85 and 4.95 , respectively). For the $50.0 \%$ of the interviewees, the execution of the Piso Fixo e Variável da Vigilância e Promoção da Saúde (PFVVPS) (Fixed and Surveillance variable and Health promotion) resources were between 75.0 and $100.0 \%$ in the past three years. When asked about the behavior of the investments in VS in the region, $50.0 \%$ of respondents referred that had increased.

In regard to the sufficiency of human resources by occupational categories, only the typists for the information systems of the VS obtained EM satisfactory (7.75). Although the remaining researched categories presented the EM below the cut-off point 
Performance indice on VS regionalization according to dimensions, attributes and overall indice. DRS-V, São Paulo, 2015.

\begin{tabular}{lcc}
\hline Dimensions / Attributes & Performance indice & Classification \\
\hline Policy & 8.16 & Satisfactory \\
Protagonism of the region & 7.15 & Satisfactory \\
Importance of regional instance & 9.16 & Satisfactory \\
Structure & 6.78 & Intermediate \\
Actions on mobilization support & 7.84 & Satisfactory \\
Financial sufficiency & 6.10 & Intermediate \\
Human resource sufficiency & 4.66 & Unsatisfactory \\
Physical resource sufficiency & 8.52 & Satisfactory \\
& & Satisfactory \\
Organization & 8.02 & Satisfactory \\
Planning and management & 8.78 & Satisfactory \\
Integrating & 8.35 & Intermediate \\
Determinants, risks and damage control to health & 6.92 & \\
Region performance & & 7.65
\end{tabular}

Table 3

Performance indice of VS regionalization according to dimension, attribute, indicator and variable. DRS-V, São Paulo, 2015

\begin{tabular}{lll}
\hline Dimension / Attribute / Indicator / Variable & EM & Classification \\
\hline POLICY & \\
Protagonism of the health region & 7,15 \\
Importance to the organs, institutions/organizations & \\
$\quad$ and spaces for decision-making on VS in the region & 7,48 \\
State Health Department (central level) & 7,48 \\
Regional Structure of the State Health Department & 6,06 \\
Civil Society Organizations & 5,50 \\
Academic Institutions & 8,06 \\
COSEMS* & 8,31 \\
CIR* & 7,15 \\
Performance on the attribution & \\
Importance of the regional instance & \\
Often meetings of the CIR on themes of VS & 9,16 \\
Performance on the attribution & 9,16 \\
\hline
\end{tabular}

Source: Elaborated by the authors

*EM: Average Score; COSEMS: City Council Health Secretaries; CIR: Regional Inter-managers Commission; PFVVPS: Fixed and Surveillance Variable and Health Promotion; HIV: Human Immunodeficiency Virus; EPI: Personal Protective Equipment; RSI: International Health Regulations; APS: Primary Health Care; ACS: Community Health Workers; ACE: Agents of Endemic Diseases Control; DOA: Compulsory Notification of Diseases; TDO: Directly Observed Therapy; SIM: Mortality Information System; Sinan: Information System on Illness Notification; Pacs: Community Health Workers Program; PSF: Family Health Program; UBS: Basic Health Unit. 
Performance indice of VS regionalization according to dimension, attribute, indicator and variable. DRS-V, São Paulo, 2015.

\begin{tabular}{|c|c|c|}
\hline Dimension / Attribute / Indicator / Variable & EM & Classification \\
\hline SYNTHETIC INDICE RESULT - Policy & 8.15 & Satisfactory \\
\hline \multicolumn{3}{|l|}{ Structure } \\
\hline \multicolumn{3}{|l|}{ Actions on mobilization support } \\
\hline Frequency on mobilizing support needed for: & 7.84 & Satisfactory \\
\hline Surveillance, prevention and transmittable disease control & 8.65 & \\
\hline $\begin{array}{l}\text { Surveillance and prevention of diseases and non-transmissible diseases } \\
\text { and their risk factors }\end{array}$ & 7.30 & \\
\hline Surveillance of the population exposed to environmental health risks & 7.52 & \\
\hline Surveillance action on worker's health & 7.30 & \\
\hline Actions to promote health and healthy lifestyle habits & 6.85 & \\
\hline Inherent risk control in products and health services & 8.42 & \\
\hline Management on information systems of VS & 8.87 & \\
\hline Performance of the attribution & 7.84 & Satisfactory \\
\hline \multicolumn{3}{|l|}{ Financial sufficiency } \\
\hline $\begin{array}{l}\text { Relative participation of federal, state and city levels in VS costing in } \\
\text { the region }\end{array}$ & 6.29 & Intermediate \\
\hline Federal & 7.07 & \\
\hline State & 4.95 & \\
\hline City & 6.85 & \\
\hline $\begin{array}{l}\text { Percentage on the deployment of resources of PFVVPS* in the region } \\
\text { over thelpast three years }\end{array}$ & 6.50 & Intermediate \\
\hline Between $75 \%$ and $100 \%$ & 3.25 & \\
\hline $100 \%$ & 3.25 & \\
\hline Investment for VS in the region over the last three years & 5.50 & Intermediate \\
\hline \multicolumn{3}{|l|}{ Increased } \\
\hline Performance of the attribution & 6.10 & Intermediate \\
\hline \multicolumn{3}{|l|}{ Human resources sufficiency } \\
\hline Human resources sufficiency for VS by professional categories & 4.66 & Unsatisfactory \\
\hline Epidemiologists (Physicians) & 3.25 & \\
\hline Sanitarians & 3.25 & \\
\hline Health Inspectors & 3.25 & \\
\hline Encoders of basic cause & 5.50 & \\
\hline Endemic agents for field actions & 3.25 & \\
\hline Typists for information systems of VS & 7.75 & \\
\hline Other professionals of superior schooling level & 5.50 & \\
\hline Other professionals of high school level & 5.50 & \\
\hline Performance of the attribution & 4.66 & Unsatisfactory \\
\hline
\end{tabular}

Source: Elaborated by the authors

*EM: Average Score; COSEMS: City Council Health Secretaries; CIR: Regional Inter-managers Commission; PFVVPS: Fixed and Surveillance Variable and Health Promotion; HIV: Human Immunodeficiency Virus; EPI: Personal Protective Equipment; RSI: International Health Regulations; APS: Primary Health Care; ACS: Community Health Workers; ACE: Agents of Endemic Diseases Control; DOA: Compulsory Notification of Diseases; TDO: Directly Observed Therapy; SIM: Mortality Information System; Sinan: Information System on Illness Notification; Pacs: Community Health Workers Program; PSF: Family Health Program; UBS: Basic Health Unit. 
Performance indice of VS regionalization according to dimension, attribute, indicator and variable. DRS-V, São Paulo, 2015

\begin{tabular}{|c|c|c|}
\hline Dimension / Attribute / Indicator / Variable & EM & Classification \\
\hline Physical resources sufficiency & & Satisfactory \\
\hline Structure sufficiency of VS in relation to the items: & 8.95 & \\
\hline Physical structure (rooms, tables, chairs, etc) & 9.10 & \\
\hline Exclusive Vehicles & 5.50 & \\
\hline Computers connected to the internet, printers and telephones & 9.10 & \\
\hline $\begin{array}{l}\text { Graphic Material for dissemination of actions, programs and } \\
\text { campaigns }\end{array}$ & 10.00 & \\
\hline $\begin{array}{l}\text { Printed and norms (forms, notification and investigation forms, } \\
\text { surveillance guides) }\end{array}$ & 10.00 & \\
\hline $\begin{array}{l}\text { Work material (paper, pen, hole puncher, stapler, scissors, glue, } \\
\text { calculator, etc.) }\end{array}$ & 10.00 & \\
\hline Frequency of procedures relating to surveillance of tuberculosis & 8.65 & Satisfactory \\
\hline Rapid test to detect HIV* on all diagnosed cases of tuberculosis & 8.87 & \\
\hline Notification of chemoprophylaxis, when necessary & 7.75 & \\
\hline Skin smear exam in all suspected cases & 8.87 & \\
\hline Antiretroviral drugs in tuberculosis co-infection cases /HIV & 8.87 & \\
\hline Basic scheme for all confirmed tuberculosis cases & 8.87 & \\
\hline $\begin{array}{l}\text { Frequency of procedures relating to surveillance and control of } \\
\text { dengue cases }\end{array}$ & 7.97 & Satisfactory \\
\hline $\begin{array}{l}\text { Availability of laboratorial diagnostic tests (serology) at regional } \\
\text { level }\end{array}$ & 8.87 & \\
\hline $\begin{array}{l}\text { Inputs from vector control (mechanical, chemical and biological } \\
\text { control of the mosquito) }\end{array}$ & 7.52 & \\
\hline $\begin{array}{l}\text { Availability of basic medication for dengue fever (oral rehydration } \\
\text { salts, dipyrone) }\end{array}$ & 7.75 & \\
\hline Availability of print (protocols for risk classification for dengue) & 8.20 & \\
\hline $\begin{array}{l}\text { Acquisition of EPI* recommended to apply insecticides and larvicides } \\
\text { in routine actions }\end{array}$ & 7.52 & \\
\hline Performance of the attribution & 8.52 & Satisfactory \\
\hline SYNTHETIC INDICE RESULT - STRUCTURE & 6.78 & Intermediate \\
\hline \multicolumn{3}{|l|}{ ORGANIZATION } \\
\hline \multicolumn{3}{|l|}{ Planning and management } \\
\hline Use of criteria for VS planning in the region & 8.43 & Satisfactory \\
\hline Epidemiological Criteria & 10.00 & \\
\hline $\begin{array}{l}\text { Characterization of the Population (socioeconomic and demographic } \\
\text { profile) }\end{array}$ & 10.00 & \\
\hline $\begin{array}{l}\text { Characterization of the environmental conditions (water supply, } \\
\text { garbage and waste collection) }\end{array}$ & 7.75 & \\
\hline
\end{tabular}

continue

Source: Elaborated by the authors

*EM: Average Score; COSEMS: City Council Health Secretaries; CIR: Regional Inter-managers Commission; PFVVPS: Fixed and Surveillance Variable and Health Promotion; HIV: Human Immunodeficiency Virus; EPI: Personal Protective Equipment; RSI: International Health Regulations; APS: Primary Health Care; ACS: Community Health Workers; ACE: Agents of Endemic Diseases Control; DOA: Compulsory Notification of Diseases; TDO: Directly Observed Therapy; SIM: Mortality Information System; Sinan: Information System on Illness Notification; Pacs: Community Health Workers Program; PSF: Family Health Program; UBS: Basic Health Unit. 
Performance indice of VS regionalization according to dimension, attribute, indicator and variable. DRS-V, São Paulo, 2015.

\begin{tabular}{|c|c|c|}
\hline Dimension / Attribute / Indicator / Variable & EM & Classification \\
\hline Dimension and network distribution of healthcare services & 10.00 & \\
\hline Results of the evaluation of the capacities of responses of RSI* & 4.38 & \\
\hline $\begin{array}{l}\text { Existence of a clear definition of managers' tasks/functions of the VS in } \\
\text { the region }\end{array}$ & 8.50 & Satisfactory \\
\hline Federal & 8.87 & \\
\hline State & 7.75 & \\
\hline City & 8.87 & \\
\hline Management guarantee of VS in the region to: & 8.66 & Satisfactory \\
\hline $\begin{array}{l}\text { Strengthening the institutional capacity (management, monitoring and } \\
\text { evaluation) }\end{array}$ & 7.75 & \\
\hline $\begin{array}{l}\text { Articulation of intra and inter-sectoral (between the VS components, } \\
\text { healthcare and other sectors) }\end{array}$ & 8.90 & \\
\hline $\begin{array}{l}\text { Information and communication production (epidemiological studies, } \\
\text { collection, processing, analysis) }\end{array}$ & 8.90 & \\
\hline $\begin{array}{l}\text { Analysis of the health situation (transmittable diseases, illness and non- } \\
\text { transmissible diseases) }\end{array}$ & 10.00 & \\
\hline Improving financial management (allocation and execution) & 7.75 & \\
\hline Management contribution of VS in the region & 9.44 & Satisfactory \\
\hline Institutional improvement & 8.87 & \\
\hline Strengthening of regional management & 10.00 & \\
\hline Strengthening of intersectoral actions & 8.87 & \\
\hline Diseases and illnesses prevention and control & 10.00 & \\
\hline Health promotion & 10.00 & \\
\hline Integration services of VS with other sectors in the region & 8.87 & \\
\hline Existence of practices and work processes of the VS & 8.88 & Satisfactory \\
\hline $\begin{array}{l}\text { Surveillance on the population's health situation (production of analyzes } \\
\text { that subsidizes planning) }\end{array}$ & 8.88 & \\
\hline $\begin{array}{l}\text { Timely detection and adopting appropriate measurements for emergency } \\
\text { response in public health }\end{array}$ & 8.88 & \\
\hline Surveillance on prevention and control of transmittable diseases & 8.88 & \\
\hline $\begin{array}{l}\text { Surveillance on non-transmittable chronic diseases, accidents and } \\
\text { violence }\end{array}$ & 7.75 & \\
\hline Surveillance on the population exposed to environmental health risks & 8.88 & \\
\hline Surveillance on workers' health & 10.00 & \\
\hline $\begin{array}{l}\text { Health surveillance on risks arising from the production and the use of } \\
\text { products, services and technologies }\end{array}$ & 8.88 & \\
\hline Performance of the attribution & 8.78 & Satisfactory \\
\hline
\end{tabular}

Source: Elaborated by the authors

*EM: Average Score; COSEMS: City Council Health Secretaries; CIR: Regional Inter-managers Commission; PFVVPS: Fixed and Surveillance Variable and Health Promotion; HIV: Human Immunodeficiency Virus; EPI: Personal Protective Equipment; RSI: International Health Regulations; APS: Primary Health Care; ACS: Community Health Workers; ACE: Agents of Endemic Diseases Control; DOA: Compulsory Notification of Diseases; TDO: Directly Observed Therapy; SIM: Mortality Information System; Sinan: Information System on Illness Notification; Pacs: Community Health Workers Program; PSF: Family Health Program; UBS: Basic Health Unit. 
Performance indice of VS regionalization according to dimension, attribute, indicator and variable. DRS-V, São Paulo, 2015

\begin{tabular}{|c|c|c|}
\hline Dimension / Attribute / Indicator / Variable & EM & Classification \\
\hline \multicolumn{3}{|l|}{ Integrating } \\
\hline The existence of intra-sectoral integration of VS & 7.75 & Satisfactory \\
\hline The existence of integration between VS and other health services & 10.00 & Satisfactory \\
\hline Importance of items to promote integration between VS and APS* & 7.31 & Satisfactory \\
\hline Joint organization of working process & 8.26 & \\
\hline Mechanisms for planning and programming & 7.93 & \\
\hline Joint practices of permanent health education & 8.08 & \\
\hline Mapping and evaluation & 8.08 & \\
\hline Participation of committees (ex: investigation of deaths) & 7.41 & \\
\hline Joint discussion of clinical cases and sentinel events & 6.89 & \\
\hline Implement home visits and/or shared services & 6.89 & \\
\hline Implement of collective actions intra and inter-sectoral territory & 7.57 & \\
\hline Joint actions between ACS* and the ACE* & 7.57 & \\
\hline Surveillance on adverse events and pharmacovigilance & 6.89 & \\
\hline Nutritional and Food Surveillance & 6.44 & \\
\hline Joint actions to promote physical activities & 5.68 & \\
\hline Performance of the attribution & 8.35 & Satisfactory \\
\hline \multicolumn{3}{|l|}{ Determinants, risks and health damage control } \\
\hline Frequency in sending laboratorial sample exams to the Health & 2.69 & Unsatisfactory \\
\hline \multicolumn{3}{|l|}{ Surveillance for analysis in another region } \\
\hline Frequency of closure laboratorial criteria cases of DNC* & 7.19 & Satisfactory \\
\hline Frequency in carrying out actions related to tuberculosis cases & 6.55 & Intermediate \\
\hline Active search for symptomatic respiratory in the territory & 5.73 & \\
\hline $\begin{array}{l}\text { Identification of tuberculosis signs and symptoms by health teams } \\
\text { and surveillance }\end{array}$ & 6.63 & \\
\hline Notification of diagnosed cases & 7.75 & \\
\hline Tuberculosis treatment according to the TDO*protocol & 7.30 & \\
\hline Pre- and post-test counseling & 7.53 & \\
\hline Active search of absentees for treatment & 7.53 & \\
\hline Closed cases in the patients' registration book & 6.40 & \\
\hline $\begin{array}{l}\text { Monitoring of tuberculosis treatment with registration for } \\
\text { monitoring }\end{array}$ & 6.40 & \\
\hline
\end{tabular}

Source: Elaborated by the authors

*EM: Average Score; COSEMS: City Council Health Secretaries; CIR: Regional Inter-managers Commission; PFVVPS: Fixed and Surveillance Variable and Health Promotion; HIV: Human Immunodeficiency Virus; EPI: Personal Protective Equipment; RSI: International Health Regulations; APS: Primary Health Care; ACS: Community Health Workers; ACE: Agents of Endemic Diseases Control; DOA: Compulsory Notification of Diseases; TDO: Directly Observed Therapy; SIM: Mortality Information System; Sinan: Information System on Illness Notification; Pacs: Community Health Workers Program; PSF: Family Health Program; UBS: Basic Health Unit. 
Performance indice of VS regionalization according to dimension, attribute, indicator and variable. DRS-V, São Paulo, 2015.

\begin{tabular}{|c|c|c|}
\hline Dimension / Attribute / Indicator / Variable & EM & Classification \\
\hline $\begin{array}{l}\text { Closed monitoring of cases treated with submission of regular and timely } \\
\text { information for the VS }\end{array}$ & 6.40 & \\
\hline Activity performance on health education on tuberculosis & 6.40 & \\
\hline Information about the epidemiological situation of tuberculosis & 5.50 & \\
\hline $\begin{array}{l}\text { Stimulate the organization and the participation of civil society in } \\
\text { tuberculosis control }\end{array}$ & 5.05 & \\
\hline $\begin{array}{l}\text { Frequency on the data related to tuberculosis generated by Sistemas de } \\
\text { Informação (SIM*, Sinan* etc.) (Information Systems) are consolidated } \\
\text { and analyzed }\end{array}$ & 8.87 & Satisfactory \\
\hline $\begin{array}{l}\text { Existence of monitoring of tuberculosis and multidrug resistant cases in } \\
\text { the region }\end{array}$ & 7.75 & Satisfactory \\
\hline Carrying out actions to control dengue fever in the region & 8.45 & Satisfactory \\
\hline $\begin{array}{l}\text { Notification of dengue cases by Unidades Básicas de Saúde/Unidades de Saúde } \\
\text { da Família (Basic Health Units/Family Health Units) }\end{array}$ & 8.88 & \\
\hline $\begin{array}{l}\text { Investigation of cases of dengue by Unidades Básicas de Saúde / Unidades de } \\
\text { Saúde da Família (Basic Health Units/Family Health Units) }\end{array}$ & 6.63 & \\
\hline $\begin{array}{l}\text { Follow-up from Sinan information with analysis of consistency, } \\
\text { completeness and data flow }\end{array}$ & 8.88 & \\
\hline $\begin{array}{l}\text { Preparation of maps to monitor the epidemiological and entomological } \\
\text { situations }\end{array}$ & 7.75 & \\
\hline $\begin{array}{l}\text { Unification of the geographical base work among the epidemiological } \\
\text { surveillance, entomological, operation field and Pacs*/PSF* (in areas } \\
\text { covered by the programs) }\end{array}$ & 8.88 & \\
\hline Disclosure for health professionals' care protocol for patients with dengue & 8.88 & \\
\hline $\begin{array}{l}\text { Training health professionals of different levels of complexity (PSF teams, } \\
\text { UBS*, emergency treatment) with specific approaches for their spheres } \\
\text { of activity }\end{array}$ & 8.88 & \\
\hline $\begin{array}{l}\text { Implementation of field activities integrated with the epidemiological } \\
\text { surveillance, health surveillance, laboratorial vigilance and } \\
\text { vectors/endemics control teams }\end{array}$ & 8.88 & \\
\hline Performance of the attribution & 6.92 & Intermediate \\
\hline SYNTHETIC INDICE RESULT - ORGANIZATION & 8.02 & Satisfactory \\
\hline
\end{tabular}

Source: Elaborated by the authors

*EM: Average Score; COSEMS: City Council Health Secretaries; CIR: Regional Inter-managers Commission; PFVVPS: Fixed and Surveillance Variable and Health Promotion; HIV: Human Immunodeficiency Virus; EPI: Personal Protective Equipment; RSI: International Health Regulations; APS: Primary Health Care; ACS: Community Health Workers; ACE: Agents of Endemic Diseases Control; DOA: Compulsory Notification of Diseases; TDO: Directly Observed Therapy; SIM: Mortality Information System; Sinan: Information System on Illness Notification; Pacs: Community Health Workers Program; PSF: Family Health Program; UBS: Basic Health Unit. 
considered satisfactory. Despite the lack in the number of professionals for the VS in the region, $100.0 \%$ of the interviewees reported that procedures for continuous formation are available to all professionals.

As to the sufficiency of physical resources, the existence of 'exclusive vehicles' (EM 5.5) obtained the worst score, being classified as intermediate. The frequency in which the actions/procedures in surveillance on tuberculosis and the monitoring and control of dengue fever cases were identified in the questionnaire and are executed by reaching the EM on the satisfactory evaluation.

\section{Organization dimension}

In respect to the control of determinants, risks and damage to health, the region also achieved satisfactory position, mainly due to the deployment of actions to control dengue fever, the frequency in which the data related to tuberculosis generated by the Sistemas de Informação (SIM, Sinan etc.) (Information Systems) are consolidated and analyzed and the frequency with which the diseases cases of compulsory notification are closed by laboratorial criteria (Table 3).

The planning of actions and VS services in the region was performed considering the epidemiological criteria (EM 10.0), the socioeconomic and demographic (EM 10.0), the dimension and distribution of the healthcare service networks (EM 10.0) and the characterization of environmental conditions (water supply, garbage and trash collection, etc) (EM 7.75). In relation to the definition of the tasks/functions of the VS managers, all the spheres (Federal, City and State) presented satisfactory evaluation (EM 8.87, 8.87 and 7.75, respectively).

In the region, there were defined practices and procedures to work towards: health surveillance of the workers (EM 10.0); surveillance on the population's health situation; timely detection and adopt appropriate measurements to respond to emergencies in public health; surveillance, prevention and the control of transmittable diseases; surveillance of the population exposed to environmental risks in health; health surveillance on risks arising from the production and the use of products, services and technologies (EM 8.87) and surveillance of chronic nontransmittable diseases, accidents and violence (EM 7.75).

In regard to the systemic integration of VS in the region, for $77.5 \%$ of the interviewees, there is integration of intra-sectoral of VS; and $100.0 \%$ of them, there is integration between VS and other health services.

When asked about what is VS role in the healthcare network (RAS) in the region, the interviewees pointed out that VS has a primordial role, because the VS accompanies the population's health situation and, thus, subsidizes the strategies to find solutions of health problems, contributing to improve the quality of life of the population and to promote health. Another respondent characterized VS as an articulator component of RAS, and the same person referred to the importance of the VS managers to participate in groups, conductors of RAS. A third interviewee said that the VS has a fundamental role in RAS, but that the Sanitary Surveillance does not fit in this role, because the inspectors of sanitations do not engage in discussions about RAS in the region.

In relation to VS role in Atenção Primária à Saúde (APS) (Primary Healthcare), the interviewees reported that the VS depends directly on the APS, because the VS executes the surveillance actions in the territory through Estratégia Saúde da Familia (ESF) (Family Health Strategy). One respondent pointed out that the VS and APS are partners, and that the VS conducts training for the ESF teams and is responsible for the logistics of actions and campaigns (vaccine, pamphlets, condoms, and so on).

To promote the integration between VS and APS in the region, the main items pointed out were: joined work process organization (EM 8.26); joined practice of permanent education in health and mapping and evaluation sets (EM 8.08); mechanisms for planning and programming (EM 7.93); the deployment of collective actions of intra and intersectoral in the territory and actions between the Agentes Comunitários de Saúde (ACS) (Community health workers) and the Agentes de Controle de Endemias (ACE) (EM 7.57) (Endemic Control Agents) and the participation in the committees, as for example, the investigation of deaths committee (EM 7.41). The remaining items of the questionnaire had scores below the cut-off point considered.

When asked about the main factors that interfere directly or indirectly in death registry poorly defined cause in the region, all the interviewees indicated the medical professional as the main responsible for this situation. The same people mentioned that these professionals had the lack of knowledge and/or commitment in regard to fill out the Declaração de Óbito (DO) (Death statement). However, three of the respondents referred that this indicator has progressed significantly in the region after the deployment of the serviço de verificação de óbito 
(SVO) (Death verification service).

According to the $75.0 \%$ of the respondents, always or almost always is necessary to send the laboratorial sample exams to the VS for analysis in another region. However, for the $75.0 \%$ of them, always or almost always the diseases cases of compulsory notification are closed by laboratory criteria.

In regard to tuberculosis cases, the frequency with which of the following actions are performed have achieved the best rating: notification on diagnosed cases (EM 7.75); pre- and post-test counseling and active search for the absentees in treatment (EM 7.52); treatment for tuberculosis cases according to the protocol of the Tratamento Diretamente Observado (TDO) (Directly Observed Therapy) (EM 7.3). The remaining items of the questionnaire were below the cut-off point, demonstrating a lower frequency of accomplishment.

For the $88.7 \%$ of the respondents, the data generated by the Sistemas de Informação (Sistema de Informação sobre Mortalidade - SIM, Sinan etc) (Information Systems - The Mortality Information System - SIM, Sinan etc) always are consolidated and analyzed. And still, according to $77.5 \%$ of them, the cases of tuberculosis and multidrug resistance are regularly monitored. However, when asked about the main difficulties to which this monitoring occurs, the respondents mentioned the fact of the secondary and tertiary references for tuberculosis treatment is located in another health region and the existence of flowing population in the region.

In relation to the execution of actions to control dengue fever, all the options in the questionnaire were EM satisfactory.

\section{Discussion}

In Brazil, despite the large number of initiatives destined to SUS consolidation and the existence of several projects driven toward the evaluation of innovations that have been deployed, there is no initiative to assess the performance of the SNVS regionalization, as a large part of the evaluations of the VS is facing its decentralization process by focusing in the city. According to Aristovinik, 18 the literature on evaluation in the health systems in the regional context is scarce and for the author to measure the effectiveness of these regional systems becomes complex due to its particular characteristics, especially to the available socioeconomic resources.

Thus, the present study proposed a performance of evaluation of the VS regionalization by taking as a basis of the three dimensions in the health system Policy, Structure and Organization - understanding that these dimensions are characterized by the conditions of the regional health dynamics. The proposed methodology demonstrated to be appropriate for evaluating the performance of the VS regionalization, especially because it was possible to identify potentialities and fragilities that can directly influence in the collection, consolidation, analysis and the dissemination of health information, as well as in the planning and the deployment in public health measurements to protect the health of the population, prevent and control risks hazards, injuries and illnesses, and promote health. ${ }^{19}$

The performance of evaluation conducted in this paper showed that the regionalization process of the VS in the studied region has obtained satisfactory results, however, for important differences among the dimensions listed in the research. It is suggested that these differences intervene of the fact in each dimension (Policy, Structure and Organization) to be influenced by differ processes.

In regard to Policy, it is noted the great influence of CIR in the overall performance of the dimension, as this was considered by the most interviewees as a permanent space for discussion of inherent issues on the VS. The regulations of the CIR were by the Decree number. 7,508, dated on June 28th, 2011, which established its functioning in health regions, 20 establishing as a space of agreement and solidary cooperation among the participants so that the health region is strengthened. 21

There is also the relevant performance of the COSEMS and the central and regional levels of the Secretaria Estadual de Saúde (State Health Department) as spaces for decision-making on VS. In relation to the latter, it is appropriate to highlight that since the publication of the Pacto pela Saúde (Health Pact), the regional territory is thought in the logic of the system, ${ }^{22}$ which began to require a new dynamic of intergovernmental relations for the advance of the decentralization by overcoming the fragmentation of decision making and the integration of the City health systems under the coordination of the State management. 23

In terms of the Structure, several studies indicate that, historically, the VS in Brazil has been constituted in the midst of a framework of precariousness human resources and physical structure. ${ }^{24,25}$ In spite of the mandatory minimum structure defined by the protocols of certification for the actions of epidemiology and disease control in the year 1999,26 in practice, this process occurred asymmetrically within the National territory, a fact that prevailed after the 
decentralization. 25 The exception in this structural context is due to the development in the financing actions of VS, with the creation of more stabled mechanisms and more available resources after the advent of decentralization. ${ }^{11}$

In relation to the Organization dimension, it was possible to perceive the importance of planning, managing and integrating intra and inter-sector for VS in the region. The contrary of Structure, over the last few years SUS organization is being consolidated by guidelines and parameters established in documents, there are examples of laws, policies or plans, in order to inform and qualify the planning and democratic management in the health system. In VS this reality is no different. Since the beginning of its decentralization process until the present day, the VS has developed mechanisms for its organization, and the Ministry of Health, through the Secretaria de Vigilância em Saúde (Health Surveillance Department), the management in actions and the coordination of SNVS.19,26

In regard to the management of VS in the health region it highlighted the strengthening of the regional management, the prevention and control of diseases and promoting health, institutional improvement, the strengthening of intersectoral actions and the integration of VS services in other sectors. It is also worth noting the analysis in the health situation; information and communication production; financial management improvement (allocation and implementation of resources) and the strengthening of institutional capacity (management, monitoring and evaluation).

Also in relation to the Organization dimension, the Decree Number 7508/2011 establishes that SUS is constituted by the set of actions and services, health protection and recovery carried out by Federal entities, directly or indirectly, being organized in a regionalized and hierarchical way. These actions and services must be offered in the health region, which should contain, the minimum of primary care; urgency and emergency; psychosocial care; specialized outpatient care and hospital; and VS. 20

In this sense, the Ministry of Health, through the Secretaria de Vigilancia em Saúde (Health Surveillance Department), establishes some services that should be provided at a regional scale, such as Public Health laboratories, Zoonoses control centers, cold chambers for immunobiologicals storage, reference centers for special immunobiologicals, storage and distribution of equipment centers, storage centers of insecticides, SVO, health services with capacity to perform procedures for high and medium complexity of diseases and disorders of the VS interest, and among others. ${ }^{27}$ Some of these services also were mentioned orally by the interviewees, and highlighting the positive impact of its actions (decreasing the number of deaths of poorly defined cause after the SVO deployment), sometimes highlighting a neediness and, consequently, its negative impact (difficulty in accompany cases of tuberculosis drug resistant due to the absence of services referred as secondary and tertiary for the tuberculosis treatment in the health region).

In spite of the regionalization is an ongoing process in SUS, it is important to highlight that the discussion around it still generates tension, even in other Countries. One example of this is a recent Canadian experience on reversal regional health processes. 28 Two main reasons can be identified: the first concerns the strong suspicion that regionalization has failed to achieve its main objectives, as for example, the increase of the access. The second reason is the deficit of almost all the Autoridades Regionais de Saúde (ARS) (Regional health authorities), equivalent to the health regions in Brazil, though, they have required more and more resources without presenting a remarkable improvement in the performance.

\section{Final Considerations}

It is expected that the State managers assume the leading role in the induction of regionalization as a government project, not limiting only to a spatial division of the State territory. Therefore, it is understood that the ability of the State manager in promoting the involvement of agents and to provoke the feeling of regional belonging is a complex task, but a crucial factor for the development of a cooperative regionalization. 14

However, to ensure that the regionalization to fulfill its role of promoting greater equity in the allocation of resources and the population's access to health services and actions at all levels of care, it becomes essential to exist between Federal entities the principle of solidarity commitment of the managers and legal and normative precepts service. This derives from the fact that the regional scope is not a new policy entity with its own budget, but dependent on the capacity, autonomy and solidarity of the three government spheres to develop a strategic vision on the use of the territory, its networks and regional specificities. ${ }^{29}$

As mentioned above, it is possible to realize the existence of operational difficulties in consolidating a regionalized health system in Brazil, especially in respect of the VS. To establish well defined boun- 
daries between the VS actions of a strictly local dimension character and those which require regional structure is, perhaps, the most important challenge. Mainly due to the lack of normative instructions that regulate the process of sharing attributions and the consequent transfer of human and material resources in the health area, as well as the absence of a regional funding source, specific to potentiate the shared actions.

In Brazil, it is clear that the central role of the Ministry of Health is to regulate the regionalization process. However, it is necessary to establish a policy project that will assume effectively the SUS regionalization as a strategy to reorganize the health care. Some challenges were identified in this study, but, in addition to it is known that the regionalization process is being associated in each State, the socioeconomic dynamics, policies on previous health, the existent articulation level among different agents and their ability to generate consensus on the division of managers' responsibilities and the adoption of regional designs. ${ }^{30}$ So it is important to evaluate the performance of regionalization in different contexts, so that it is possible to understand the dynamics of VS regionalization in Brazil.

\section{References}

1. Teixeira CF, Solla JP. Modelo de atenção à Saúde no SUS trajetória do debate conceitual, situação atual, desafios e perspectivas. In: Lima NT, Gerchman S, Edler FC, Suárez JM, editor. Saúde e Democracia: história e perspectiva do SUS. Rio de Janeiro: Editora Fiocruz; $4^{\mathrm{a}}$ reimpressão, 2015. p. 504.

2. Viana ALD, Fausto MCR, Lima LD. Política de saúde e equidade. São Paulo Perspect. 2003; 17 (1): 58-68.

3. Vargas I, Mogollón PAS, Unger JP, De Paepe P, Vázquez ML. Regional-based Integrated Healthcare Network policy in Brazil: from formulation to practice. [internet]. Health Policy Plann; 2014; 30 (6): 705-17.

4. Souza C. Governos e sociedades locais em contextos de desigualdades e de descentralização. Ciênc Saúde Coletiva. 2002; 7 (3): 431-42.

5. Fracolli LA, Faria LS, Pereira JG, Melchior R, Bertolozzi MR. Vigilância à Saúde: deve se constituir como política pública? Saúde Soc. 2008; 17 (2): 184-92.

6. Faria LS, Bertolozzi MR. Aproximações teóricas acerca da vigilância à saúde: um horizonte para a integralidade. Acta Paul Enferm. 2009; 22 (9): 422-7.

7. Costa JMBS, Cesse EAP, Samico IC, Carvalho, EMF. Avaliação do desempenho estadual da vigilância em saúde de Pernambuco Abstract. Physis. 2015; 25 (4): 1141-63.

8. Larhey R, Nielsen SB. Rethinking the relationship among monitoring, evaluation and results based management observations from Canada. New Directions for Evaluation. 2013; 137: 45-56.

9. Marchal B, Hoerée T, Silveira VC, Belle SV, Prashanth N, Kegels G. Building on the EGIPSS performance assessment: the multipolar framework as a heuristic to tackle the complexity of performance of public service oriented health care organizations. BMC Public Health. 2014; 14: 378-91.

10. Viacava F, Almeida C, Caetano R, Fausto M, Macinko J, Martins M, Noronha JC, Novaes HMD, Oliveira ES, Porto SM, Silva LMV, Szwarcwald CL. Uma metodologia de avaliação do desempenho do sistema de saúde brasileiro. Ciênc Saúde Coletiva. 2004; 9 (3): 711-24.
11. Silva Júnior JB. Epidemiologia em serviço: uma avaliação de desempenho do Sistema Nacional de Vigilância em Saúde. [tese] Campinas: Universidade Estadual de Campinas; 2004.

12. Teixeira GM, Costa MCN, Souza LP, Nascimento EMR, Barreto ML, Barbosa N, Carmo EH. Evaluation of Brazil's public health surveillance system within the context of the International Health Regulations. Rev Panam Salud Pública. 2012; 32 (1): 49-55.

13. Viana ALD, Bousquat A, Pereira APCM, Uchimura LYT, Albuquerque MV, Mota PHS, Demarzo MMP, Ferreira MP. Tipologia das regiões de saúde: condicionantes estruturais para a regionalização no Brasil. Saúde Soc. 2015; 24 (2): 413-22.

14. Reis YAC, Cesse EAP, Carvalho EF. Consensos sobre o papel do gestor estadual na regionalização da assistência à saúde no Sistema Único de Saúde (SUS). Rev Bras Saúde Matern Infant. 2010; 10 (supl. 1): 157-72.

15. Likert R. Una Técnica para la Medicion de Atitudes. In: Weinerman CH. Escalas de Medicion en Ciências Sociales. Buenos Aires: Nueva Vision; 1976. p.201-60.

16. Kessner DM, Kalk CE, Singer J. Assessing health quality: the case for tracers. New Engl J Med. 1973; 288 (4): 18994.

17. Minayo MCS. O desafio do conhecimento: pesquisa qualitativa em saúde. São Paulo: Hucitec; 2010

18. Aristivinik A. Regional Performance Measurement of Healthcare Systems in the EUA Nonparametric Approach. Lex localis - J Local Self-Government. 2015; 13 (3): 57993.

19. Brasil. Ministério da Saúde. Portaria ${ }^{\circ} 1.378$, de 9 de julho de 2013. Regulamenta as responsabilidades e define diretrizes para execução e financiamento das ações de Vigilância em Saúde pela União, Estados, Distrito Federal e Municípios, relativos ao Sistema Nacional de Vigilância em Saúde e Sistema Nacional de Vigilância Sanitária. Diário Oficial da União 2013; 10 jul. 
20. Brasil. Ministério da Saúde. Decreto $n^{0} 7.508$, de 28 de junho de 2011. Regulamenta a Lei $\mathrm{n}^{\circ} 8.080$, de 19 de setembro de 1990, para dispor sobre a organização do Sistema Único de Saúde - SUS, o planejamento da saúde, a assistência à saúde e a articulação interfederativa e dá outras providências. Diário Oficial da União 2011; 29 jun.

21. Santos AM, Giovanella L. Governança regional: estratégias e disputas para gestão em saúde. Rev Saúde Pública. 2014; 48 (4): 622-31.

22. Viana ALD. Ibañez N, Elias PEM, Lima LD, Albuquerque MV, Iozzi FL. Novas perspectivas para a regionalização da saúde. São Paulo Perspect. 2008; 22 (1): 92-106.

23. Brasil. Ministério da Saúde. Portaria GM/MS no 399 de 22 de fevereiro de 2006. Divulga o Pacto pela Saúde 2006 Consolidação do SUS e aprova as Diretrizes Operacionais do Referido Pacto. Diário Oficial da União 2006; 22 fev.

24. Simoes EJ, Ramos LR, McDuffey KY, Luo YH. Evaluation of Epidemiological Surveillance Capacity and Needs in Five Brazilian States: A Report to the World Bank - Brazil. Centers for Disease Control and Prevention, Division of Adult and Community Health; 2004. p. 120

25. Albuquerque AC, Mota ELA, Felisberto E. Descentralização das ações de vigilância epidemiológica em Pernambuco, Brasil. Cadernos de Saúde Pública. 2015; 31 (4): 861-73.

Received on June 2nd, 2017

Final version presented on August 17th, 2017

Approved on September 18th, 2017
26. Brasil. Ministério da Saúde. Portaria $\mathrm{n}^{0} 1.399$, de 15 de dezembro de 1999. Regulamenta a NOB SUS 01/96 no que se refere às competências da União, estados, municípios e Distrito Federal, na área de epidemiologia e controle de doenças, define a sistemática de financiamento e dá outras providências. Diário Oficial da União 1999; 15 dez.

27. Brasil. Ministério da Saúde. Secretaria de Vigilância em Saúde. Diretoria de Apoio à Gestão em Vigilância em Saúde. Manual de gestão da Vigilância em Saúde. Brasília, DF; 2009. p. 80.

28. Marchildon GP. The crisis of regionalization. Healthc Manage Forum. 2015; 28 (6): 236-8.

29. Albuquerque MV, Viana ALD. Perspectivas de região e redes na política de saúde brasileira. Saúde Debate. 2015; 39: $28-38$.

30. Lima LD, Viana ALD, Machado CV, Albuquerque MV, Oliveira RG, Iozzi FL, Scatena JHG, Mello GA, Pereira AMM, Coelho APS. Regionalização e acesso à saúde nos estados brasileiros: condicionantes históricos e políticoinstitucionais. Ciênc Saúde Coletiva. 2012; 17 (11): 288192. 